\title{
Effects of food availability on survival, growth, and reproduction of the grass shrimp Palaemonetes pugio: a laboratory study
}

\author{
Kathleen A. Reinsel ${ }^{1, *}$, Patricia S. Glas ${ }^{2}$, James R. Rayburn ${ }^{3}$, M. Karen Pritchard ${ }^{4}$, \\ William S. Fisher ${ }^{5}$ \\ ${ }^{1}$ Department of Biology, Wittenberg University, PO Box 720, Springfield, Ohio 45504, USA \\ ${ }^{2}$ Department of Biology, The Citadel, 171 Moultrie Street, Charleston, South Carolina 29409, USA \\ ${ }^{3}$ Department of Biology, Jacksonville State University, 700 Pelham Road. N., Jacksonville, Alabama 36265-1602, USA \\ ${ }^{4}$ Biology Department, Pensacola Junior College, Pensacola, Florida 32504, USA \\ ${ }^{5}$ Gulf Ecology Division, National Health and Environmental Effects Research Laboratory, \\ US Environmental Protection Agency, Gulf Breeze, Florida 32561, USA
}

\begin{abstract}
Grass shrimp are abundant, ecologically important inhabitants of estuarine ecosystems that have been used extensively in laboratory experiments. However, optimal laboratory feeding conditions have not been determined. We used a laboratory experiment to determine the effects of food availability on survival, growth and reproduction in adult Palaemonetes pugio Holthuis and hatching success of their offspring. Fifteen groups of 50 shrimp were fed 1 of 5 rations of TetraMin ${ }^{\circledR}$ flake food, a standard laboratory diet, for $12 \mathrm{wk}$; supplementary amounts of newly hatched Artemia sp. nauplii were also given twice weekly. Adult survival, female reproductive condition, and embryo hatching success were determined every $2 \mathrm{wk}$. Growth was determined from measurements at the beginning and end of the study. Limited food availability caused severe mortality and reduced growth of female shrimp, whereas male shrimp were not affected. Reproduction, as measured by percent gravid females and individual clutch size, was not affected by food availability. However, estimated population-level embryo production was reduced indirectly for the lower rations through mortality and smaller size of females. Hatching success was low in all treatments. Further studies are needed to determine optimal laboratory feeding conditions for grass shrimp so they may be better utilized as predictors of responses in the field.
\end{abstract}

KEY WORDS: Feeding $\cdot$ Reproduction $\cdot$ Grass shrimp $\cdot$ Palaemonetes $\cdot$ Food limitation $\cdot$ Nutrition $\cdot$ Hatching success

Resale or republication not permitted without written consent of the publisher

\section{INTRODUCTION}

Grass shrimp are conspicuous inhabitants of estuaries throughout the United States. Three species that often co-occur along the Atlantic and Gulf Coasts, Palaemonetes pugio Holthuis, $P$. vulgaris Say and $P$. intermedius Holthuis, can comprise up to $56 \%$ of the total abundance of pelagic macrofauna in estuarine

*E-mail: kreinsel@wittenberg.edu tidal creeks (Scott et al. 1992). As deposit-feeding omnivores, grass shrimp break down decaying marsh grass and thereby influence the cycling of nutrients, particulates and energy in estuarine systems (Welsh 1975). In addition, they are important prey for early and juvenile life stages of several commercially important fish species, including red drum and spotted sea trout (Gunter 1945, Moody 1950, Wenner 1995, Wenner \& Archambault 1996). Because of their ecological significance, they have potential utility as sentinels of ecosystem integrity. To develop this 
potential, it is important that we understand the biological characteristics of grass shrimp and environmental factors that influence their survival, growth, and reproduction.

Like many decapod crustaceans, development of grass shrimp embryos occurs externally on the pleopods of the female. The reproductive pattern of grass shrimp is similar to that described for Palaemonetes varians (Antheunisse et al. 1968) and P. kadiakensis (White 1949). Soon after a female molts, 1 or more males may deposit spermatophores externally on her ventral thorax. Eggs are extruded within 2 to $3 \mathrm{~h}$ of mating, fertilized as they pass over the spermatheca, and attached with 'glaire' or cement to pleopodal setae that form the incubation chamber (Williams 1984). During the embryonic development period (roughly 2 wk during summer months, but dependent on temperature) the female may re-initiate oogenesis to provide new ova for extrusion at the next molt (White 1949). Reproduction in Palaemonetes species in the field occurs from early spring through fall, depending upon the location.

Because of their ecological importance and their relative hardiness in the laboratory, grass shrimp have historically been used in a variety of laboratory experiments. These range from studies of their physiology (e.g. Goddard \& Forward 1991, Okazaki \& Freeman 1993) and ecology (e.g. Bell \& Coull 1978, Kneib 1987, Olmi \& Lipcius 1991, Vernberg \& Piyatiratitivorakul 1998) to toxicology studies (e.g. Tatem et al. 1976, Wilson et al. 1985, Weis et al. 1992, Khan et al. 1993, Key et al. 1998). Due to the relatively short developmental period, embryos of Palaemonetes pugio have recently been used in an in vitro assay to examine developmental effects of environmental toxicants (Fisher \& Foss 1993, Rayburn et al. 1996, Rayburn \& Fisher 1997, 1999, Shelton et al. 1999).

Results of toxicological studies using grass shrimp adults and embryos have the potential to be extremely useful in predicting the effects of environmental contaminants in field situations. However, for laboratory results to be interpreted accurately, it is imperative that laboratory holding conditions be appropriate for survival, growth and reproduction of adult shrimp. In particular, an optimal diet for production of viable offspring is essential for studies involving shrimp embryos. Although the subject of food quality has been extensively studied for shrimp species used in aquaculture (e.g. review by Harrison 1990), specific studies addressing nutritional requirements for adult survival, growth, and production of viable embryos have not been performed for Palaemonetes species. In this study we performed a laboratory experiment examining the effects of food availability on survival, growth and reproductive output of $P$. pugio.

\section{MATERIALS AND METHODS}

Field collection. Approximately 1500 grass shrimp were collected with dip nets on 5 August 1997 from the Escambia River near Pensacola, Florida, USA. Shrimp were collected from a 30 m-long stretch of sandy shoreline with Spartina alterniflora growing along the bank. On the day of collection, water temperature was $30^{\circ} \mathrm{C}$ and salinity was $10 \mathrm{ppt}$. Shrimp were transported to the laboratory in coolers containing water from the collection site. Water in the coolers was aerated, and shrimp were maintained in the coolers overnight. In the laboratory, the salinity of the water in the coolers was raised in increments of 2 to 4 ppt every 4 to $6 \mathrm{~h}$ to acclimate shrimp to 20 ppt used in experimental holding aquaria, which were fed by flowing, filtered seawater.

Laboratory conditions. On the day after field collection, 30 female and 20 male grass shrimp identified as Palaemonetes pugio Holthuis (Williams 1984) were randomly assigned to each of 15 aquaria (40 l). The total length of each shrimp, from the tip of the rostrum to the end of the telson, was measured with calipers to the nearest $0.1 \mathrm{~mm}$. In addition, the presence or absence of egg masses on the pleopods and visible oocytes in the ovary were recorded for all female shrimp.

To examine the effects of food availability on survival, growth and reproduction, grass shrimp were maintained on 5 different food rations in a $12 \mathrm{wk}$ laboratory experiment (6 August to 30 October 1997). Three replicate $40 \mathrm{l}$ aquaria for each of the 5 food treatments were arranged in a randomized block design. Aquaria were supplied with flow-through filtered, salinity-controlled (20 ppt) seawater and were aerated with airstones. The flow rate and aeration were similar in all aquaria and were monitored daily. The room was maintained on a $16 \mathrm{~h}: 8 \mathrm{~h}$ light:dark cycle and aquaria were covered with $1 / 4$ inch $(6.4 \mathrm{~mm})$ plastic mesh to prevent escape of shrimp.

Shrimp were fed daily with 1 of 5 different amounts of TetraMin ${ }^{\circledR}$ Standard Mix flake food (TetraWerke, Melle, Germany). Previous experience with laboratory culture had shown that a daily ration of $0.025 \mathrm{~g}$ shrimp $^{-1}$ resulted in little excess food after $24 \mathrm{~h}$ (Foss \& Rayburn 1997). This standard ration was selected as 1 of the 5 experimental treatments. The other treatments were $1 / 4,1 / 2,2$ and 4 times the standard ration, resulting in daily food rations ranging from 0.0062 to $0.1 \mathrm{~g}$ shrimp $^{-1}$. The shrimp were fed at the same time each day. In order to maintain a constant amount of food per shrimp, the total food amounts were adjusted every $2 \mathrm{wk}$ to compensate for any mortalities that occurred in the aquaria. Equal numbers of newly hatched Artemia sp. nauplii were added to each aquarium twice weekly as a supplemental food source, since many crustaceans 
cannot synthesize cholesterol and some polyunsaturated fatty acids (Whitney 1969, 1970, Kanazawa \& Teshima 1971). Naupliar concentrations $\left(100 \mathrm{l}^{-1}\right.$ in all aquaria) were significantly lower than the $5000 \mathrm{l}^{-1}$ typically used to rear crustacean larvae (Welch \& Epifanio 1995) in order to prevent significant alteration of the food levels in the lower treatments.

Measurements. Aquaria were examined daily for the presence of gravid females, dead individuals and the amount of food remaining in each aquarium. The water quality in all aquaria was analyzed weekly. Temperature and dissolved oxygen measurements were made using a hand-held Orion 820 oxygen meter; $\mathrm{pH}$ measurements were made using a countertop Orion 520A pH meter. Ammonia was tested using a TetraTest $^{\circledR}$ Ammonia test kit (TetraWerke). After weekly water quality measurements, excess food was siphoned from the aquaria and dead individuals were removed.

A census was conducted every 2 wk, during which all shrimp were removed from the aquaria for observation. The number and gender of survivors were recorded. The presence or absence of incubating egg masses on the pleopods and developing oocytes in the ovary were recorded for all female shrimp; the developmental stage of the embryos in egg masses (Wilson 1985, Glas et al. 1997) was also noted. In addition, 1 female shrimp with embryos that were $3 \mathrm{~d}$ postoviposition was removed from each aquarium at each census. Embryos were removed from the female, separated and counted to determine clutch size. The embryos from each female were placed individually into wells of a 24-well plastic tissue culture plate with $2 \mathrm{ml}$ of filtered seawater. This method has been used successfully (100\% hatching success) in an in vitro assay to study the effects of toxicants on embryo development (Fisher \& Foss 1993, Rayburn et al. 1996). Development of the embryos was monitored daily, and mortality or survival to hatch was recorded for each embryo. The females used for these measurements were not returned to the aquaria. If none of the females in any particular aquarium were carrying 3 day-old embryos, then 1 of the remaining females was removed from the aquarium to ensure that removals were constant across all aquaria.

Analysis. All analyses were performed with Statview (Abacus Concepts 1992) or SuperANOVA (Abacus Concepts 1989) software as detailed below. All data expressed as proportions were arcsine-transformed prior to analysis (Sokal \& Rohlf 1981). Significant foodration main effects were followed by Tukey-Kramer post-hoc comparisons (Sokal \& Rohlf 1981). For repeated-measures analyses, significant time main effects were followed by single degree-of-freedom orthogonal polynomial contrasts (Zar 1996). Significant interaction effects in repeated-measures designs were followed by 1-way ANOVAs for each sampling time.

Survival data were analyzed with separate 2-way (ration, time) repeated-measures ANOVAs for female and male shrimp. Data were expressed as the proportion of the initial number of shrimp that survived to each census. Since 1 female shrimp was removed from each aquarium for embryo survival tests at each census, proportions of female survivors were corrected for these removals.

Growth data were analyzed separately for female and male shrimp. Nested ANOVAs (replicate aquaria nested within food treatment) were performed on the size of the shrimp at the start of the experiment, to ensure that mean sizes of shrimp in each treatment did not differ by chance. A second set of nested ANOVAs performed on data collected at the end of the experiment determined the effect of food ration on shrimp size. In addition, average sizes of female and male shrimp at the beginning and the end of the experiment were compared with separate 2-way repeated-measures ANOVAs. In order to avoid pseudoreplication (Hurlbert 1984), the mean size of shrimp in each aquarium was used for these comparisons rather than comparing individuals.

The number of gravid female shrimp in each treatment at each census were compared with a 2-way repeated-measures ANOVA. To correct for differential survival in the different food treatments, the data were expressed as proportions. Some female shrimp had visible oocytes in their ovaries while they were gravid; therefore neither of these single measurements indicated the overall reproductive condition of the shrimp. A reproductive score was calculated to assess the overall reproductive condition of each female: shrimp that were not gravid and had no visible oocytes were given a score of 0 ; shrimp that were either gravid or had visible oocytes were given a score of 1 ; and shrimp that were gravid and also had visible oocytes were given a score of 2. To correct for differential survival in the different food treatments, mean scores were calculated for each tank. These mean reproductive scores were compared with a 2-factor repeated-measures ANOVA.

A 2-way ANCOVA was used to determine the effects of food ration and time on the number of embryos produced by each female. Since female size has been shown to affect the number of embryos produced per clutch (Wood 1967), length of the female was used as the covariate. In addition to determining the clutch size for individual female shrimp, we also estimated the total number of embryos produced in each aquarium at each census. From the individual clutch sizes measured for each aquarium at a given census, a mean clutch size was determined for each of the treatments ( $\mathrm{n}=3$ per treatment). This mean clutch size was then 
multiplied by the number of gravid females in each aquarium in that treatment to provide an estimate of the total number of embryos in each aquarium. Estimates were calculated for each aquarium at each census and a 2-way repeated-measures ANOVA was used to compare the estimated totals. Cumulative estimated total embryo production was also calculated for each aquarium by summing the estimates from all previous times. The cumulative totals for $12 \mathrm{wk}$ were compared with a 1-way ANOVA.

Embryo survival potential in each food treatment at each census was compared with a 2-factor ANOVA. The proportion of embryos surviving to hatch was used in the analysis. In all statistical analyses, statistical significance was recognized at $\mathrm{p} \leq 0.05$.

\section{RESULTS}

\section{Water quality}

Water temperatures in the aquaria were initially $28-29^{\circ} \mathrm{C}$, but as the experiment progressed into the fall months and the temperature of the external water supply dropped, temperatures in the aquaria gradually declined to $23-24^{\circ} \mathrm{C}$. Water salinity was maintained at 18-20 ppt in all aquaria. These parameters are within acceptable ranges for grass shrimp survival and repro-

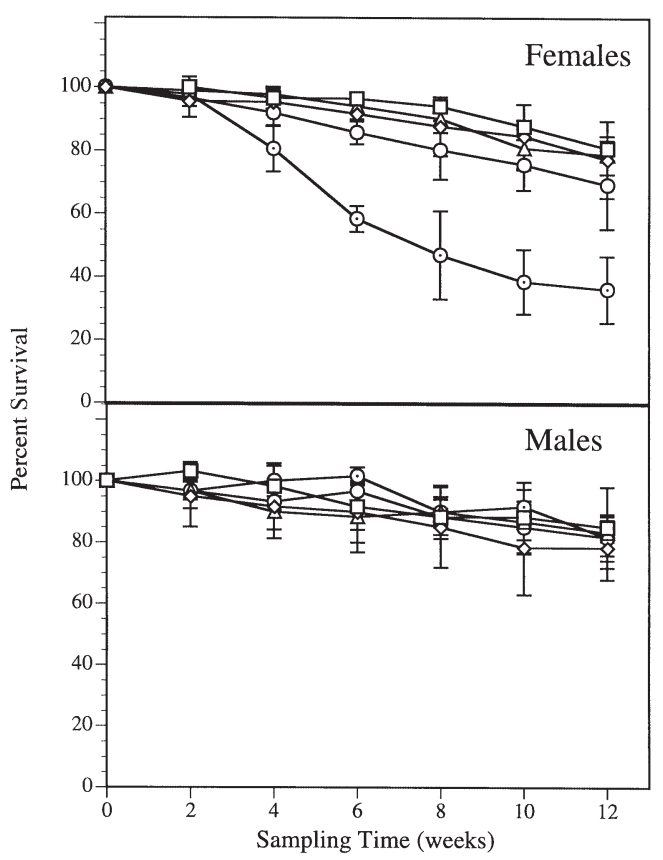

Fig. 1. Palaemonetes pugio. Mean percent $( \pm 1 \mathrm{SD}, \mathrm{n}=3)$ of females and males surviving to each census date $(\mathrm{n}=3$ replicates). Treatments were $4 \times(\square), 2 \times(\diamond), 1 \times(\Delta), 1 / 2 \times(0)$ and

$1 / 4 \times(\odot)$ a standard ration of $0.0125 \mathrm{~g} \mathrm{shrimp} \mathrm{d}^{-1}$ duction of Palaemonetes pugio (Wood 1967). Dissolved oxygen in all aquaria ranged from 6.8 to $8.7 \mathrm{ppm}$ over the course of the experiment. The $\mathrm{pH}$ range was 7.65 to 8.36, within standard values for seawater (Sverdrup et al. 1942). Ammonia concentrations in the aquaria ranged from 0 to $0.052 \mathrm{ppm}$, which is acceptable for marine organisms (Riley \& Chester 1971).

\section{Adult survival}

The density of female shrimp decreased significantly in all treatments over time $\left(F_{6,60}=118.7, \mathrm{p}<0.001\right)$, but the decrease was significantly more pronounced in the lowest food treatment (significant ration $\left[F_{4,10}=10.2, \mathrm{p}\right.$ $<0.01]$ and interaction $\left[F_{24,60}=4.42, \mathrm{p}<0.001\right]$ effects; Fig. 1). After $12 \mathrm{wk}, 69.3$ to $78.7 \%$ of the shrimp still remained in the 4 higher treatments, while only $36.0 \%$ remained in the lowest food treatment. Male density also decreased over time $\left(F_{6,60}=32.2, \mathrm{p}<0.001\right)$, but this decrease was the same for all food treatments (no significant effect of ration $\left[F_{4,10}=0.6, \mathrm{p}>0.05\right]$ and no significant interaction $\left.\left[F_{24,60}=1.1, \mathrm{p}>0.05\right]\right)$. After $12 \mathrm{wk}$, an average of $82.0 \%$ of the male shrimp were still alive (Fig. 1).

\section{Growth}

At the beginning of the experiment there were no significant differences among treatments in the average size of female $\left(F_{4,435}=0.50, \mathrm{p}>0.05\right)$ or male $\left(F_{4,285}=0.4, \mathrm{p}>0.05\right)$ shrimp. Females averaged 29.2 $( \pm 0.6) \mathrm{mm}$ in total length, whereas males averaged $23.1( \pm 1.0) \mathrm{mm}$ (Fig. 2). After $12 \mathrm{wk}$, female shrimp were significantly larger than at the beginning of the experiment $\left(F_{1,10}=174.1, \mathrm{p}<0.001\right)$ and females from higher food treatments were larger (33 to $34 \mathrm{~mm}$ ) than those from the lower food treatments (31 to $32 \mathrm{~mm}$ ) $\left(F_{4,238}=10.4, \mathrm{p}<0.001\right)$. Male shrimp were also significantly larger $(27.3 \pm 0.6 \mathrm{~mm})$ after $12 \mathrm{wk}\left(F_{1,10}=259.8\right.$, $\mathrm{p}<0.001)$. However, the average size of male shrimp did not differ between the different food treatments $\left(F_{4,10}=0.7, \mathrm{p}>0.05\right.$; Fig. 2).

\section{Reproduction}

Proportion of gravid females

Although there was a slight trend toward lower proportions of gravid females in the lower food treatments (Fig. 3A), the proportion of gravid female shrimp was not significantly affected by the amount of food they received $\left(F_{4,10}=2.9, \mathrm{p}=>0.05\right)$. Overall, 38.4 to $50.4 \%$ 


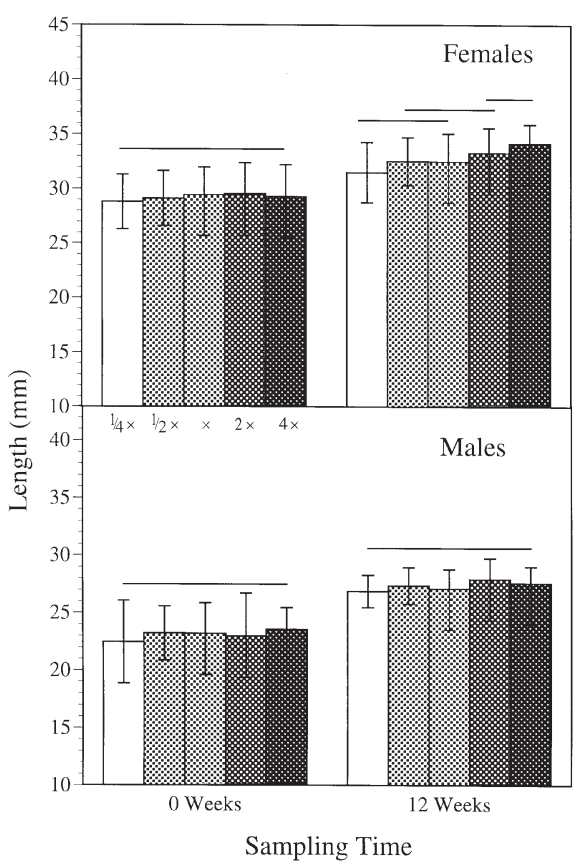

Fig. 2. Palaemonetes pugio. Mean total length $( \pm 1 \mathrm{SD}, \mathrm{n}=3)$ of females and males at the beginning $(0 \mathrm{wk})$ and end $(12 \mathrm{wk})$ of the experiment. Progressive shading of bars from light to dark indicates increases in amount of food per shrimp, from $1 / 4 \times$ to $4 \times$ a standard ration, $\left(x=0.0125 \mathrm{~g}\right.$ shrimp $\left.\mathrm{d}^{-1}\right)$. Lines above bars indicate nonsignificant subsets (Tukey-Kramer post-hoc comparison: Sokal \& Rohlf 1981)

of the females in the experiment were gravid at any given time. The average proportion of gravid females, however, did decrease significantly over the course of the experiment $\left(F_{6,60}=6.3, \mathrm{p}<0.001\right.$; significant 1 storder orthogonal polynomial contrast, $F=15.0, \mathrm{p}<$ $0.001)$. In addition, a significant 5 th-order contrast $(F=$ 13.0, $\mathrm{p}<0.001$ ) indicated that the percentages of gravid females after 4 and $10 \mathrm{wk}$ were lower than on other sampling dates (Fig. 3B).

\section{Reproductive score}

The overall reproductive condition of individual female shrimp, as described by reproductive score, was significantly affected by food ration $\left(F_{4,10}=9.0, \mathrm{p}<\right.$ 0.01). Reproductive score also varied significantly over the course of the experiment $\left(F_{6,60}=19.4, \mathrm{p}<0.001\right)$, but was typically lower at the lowest ration $\left(F_{24,60}=2.9\right.$; $\mathrm{p}<0.001)$. The average reproductive score for all treatments except the lowest food ration was approximately 1.2 at all census times except $4 \mathrm{wk}$, when it was significantly lower (0.91: Fig. 4). Shrimp that received the lowest food ration showed a similar reduction in repro-
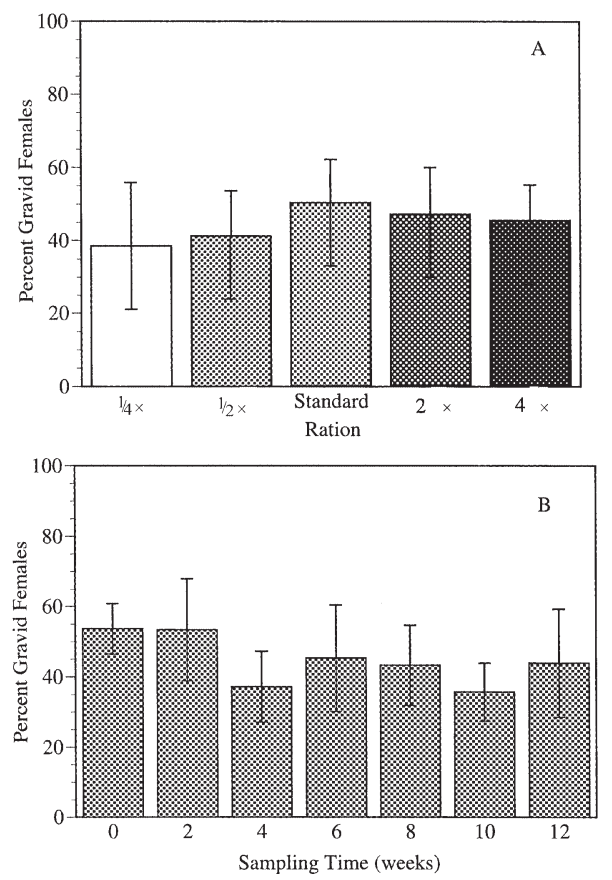

Fig. 3. Palaemonetes pugio. Mean $\%$ females $( \pm 1 \mathrm{SD}, \mathrm{n}=3)$ carrying embryos in the (A) 5 food treatments and (B) at each census

ductive score at $4 \mathrm{wk}$ (Fig. 4). However, this reduction was more dramatic, and the score remained significantly lower than the other treatments until the 10 week sampling. At 10 and $12 \mathrm{wk}$, there were no differences in the reproductive scores of females in the 5 food treatments.

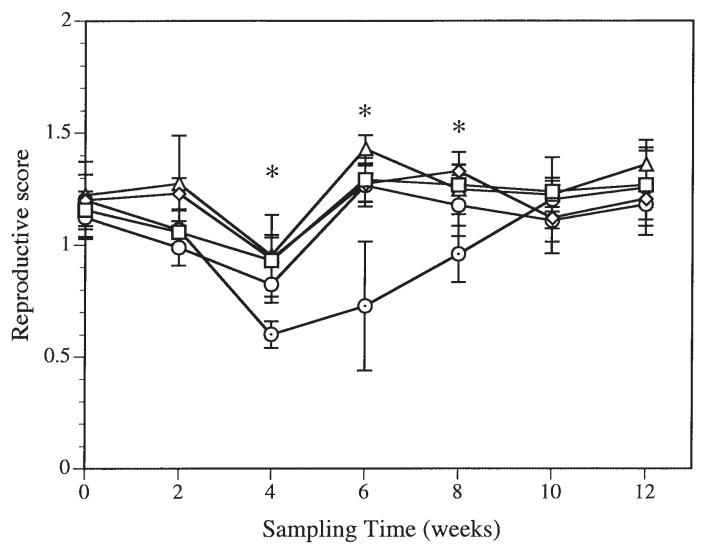

Fig. 4. Palaemonetes pugio. Mean reproductive score $( \pm 1 \mathrm{SD}$ $\mathrm{n}=3$ ) for females in each food treatment at each census. Score of $0=$ gravid and no visible oocytes, $1=$ gravid or oocytes visible, $2=$ gravid and oocytes visible. Treatments were $4 \times(\square), 2 \times(\diamond), 1 \times(\Delta), 1 / 2 \times(0) ; 1 / 4 \times(\odot)$ a standard ration of $0.0125 \mathrm{~g} \mathrm{shrimp}^{-1}$. *significant differences at that sampling time (1-way ANOVA) 


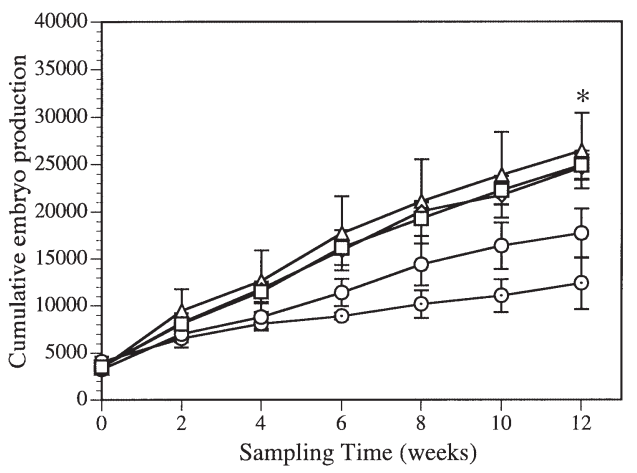

Fig. 5. Palaemonetes pugio. Mean cumulative estimated embryo production $( \pm 1 \mathrm{SD}, \mathrm{n}=3)$ per aquarium in each food treatment at each census. Further details as in legend to Fig. 4

\section{Clutch size}

The number of embryos produced by an individual female (clutch size) was not significantly affected by the amount of food available $\left(F_{4,55}=1.9, \mathrm{p}>0.05\right)$, nor did the numbers change significantly over time $\left(F_{5,55}=\right.$ 1.3, p > 0.05). Mean clutch size ranged from $205.3( \pm$ $72.5)$ to $372.0( \pm 63.0)$. There was, however, a significant relationship between the length of the female shrimp and the number of embryos produced $\left(F_{1,84}=\right.$ 16.3, $\mathrm{p}<0.001$ ). This relationship is best described by the model: number of eggs $=12.28 \times$ total length -85.3 $\left(\mathrm{R}^{2}=0.162\right)$.

In contrast to embryo production per female, embryo production per aquarium was affected by ration and varied over time (ration: $F_{4,10}=19.5, \mathrm{p}<0.001$; time: $\left.F_{6,60}=16.0, \mathrm{p}<0.001\right)$. In addition, the differences among treatments varied over time $\left(F_{6,24}=16.0, \mathrm{p}<\right.$ 0.001). At Week 0, aquaria in all treatments produced

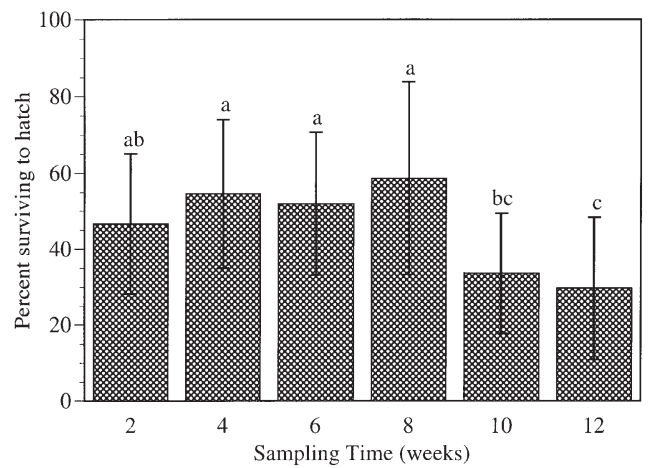

Fig. 6. Palaemonetes pugio. Mean \% survival ( $\pm 1 \mathrm{SD}, \mathrm{n}=3$ ) of embryos to hatch. At each census, embryos were incubated individually in 24-well tissue-culture plates with filtered seawater for $12 \mathrm{~d}$. Bars with same letters are not significantly different (Tukey-Kramer post-hoc comparison: Sokal \& Rohlf 1981) approximately 3500 embryos. The overall average was slightly higher after 2 wk (4200) and, although variation among treatments was larger, there were no differences among treatments. After the 2 wk census, there was a gradual decline in estimated total embryo production in all treatments. However, from 4 until $10 \mathrm{wk}$, aquaria receiving the lowest ration produced significantly fewer embryos ( $\leq 1500$ at each census) than most other treatments (2000 to 5000 embryos per aquarium). By the end of the experiment, production in all treatments was reduced to an average of 2100 per aquarium and there were no differences among treatments.

Since embryos were produced in each treatment throughout the experiment, cumulative embryo production (estimated) increased over time in all treatments (Fig. 5). After 12 wk, cumulative embryo production was significantly different among rations $\left(F_{4,10}=\right.$ 15.67, $\mathrm{p}<0.001)$. In standard $(1 \times), 2 \times$ and $4 \times$ rations, a total of $>24000$ embryos were produced. The lower 2 rations produced significantly fewer total embryos over the course of the experiment $(1 / 4 \times$ and $1 / 2 \times$ rations produced 12000 and 18000, respectively: Fig. 5).

\section{Embryo success}

There was no significant effect of ration on survival of embryos to hatch $\left(F_{4,56}=0.5, \mathrm{p}>0.05\right.$; Fig. 6$)$ at any of the sampling intervals. However, average embryo survival was different at different sampling times during the experiment $\left(F_{5,56}=1.0, \mathrm{p}<0.001\right)$. After $2 \mathrm{wk}$ of the experiment, survival was $46.6 \pm 18.5 \%$. Survival then increased to $>50 \%$ for the next 3 sampling periods. However, after $10 \mathrm{wk}$, survival decreased to < $35 \%$ and remained low until the end of the experiment (Fig. 6).

\section{DISCUSSION}

This study demonstrated that laboratory-induced food limitation impacted survival and growth of female grass shrimp Palaemonetes pugio, creating indirect effects on population-level reproductive output. Low food availability significantly reduced survival and growth of females even though it had no effect on survival or growth of males. The reproductive effort of surviving females, as measured by the percentage of gravid females and length-normalized clutch sizes of individual females, was unaffected by low food availability. However, since clutch size is proportional to female length, population-level reproductive output was reduced through both decreased female survival and decreased female growth in the lower food treatments. Finally, embryo hatching success was dramati- 
cally and inexplicably lower than has been shown in other studies that used the same methods, and there were no differences among treatments. These data imply that success of grass shrimp populations in the field during periods of low food availability may depend on the transfer of metabolic energy and material to reproduction (egg production) rather than to survival and growth of mature females.

Female shrimp in low-food treatments showed striking reductions in both survival and growth (Figs 1 \& 2). Females in aquaria fed $1 / 4 \times$ the standard ration exhibited $36 \%$ survival and $32 \mathrm{~mm}$ average total length after $12 \mathrm{wk}$ in the laboratory, whereas all other treatments ( $1 / 2$ to $4 \times$ rations) exhibited survival ranging from 69 to $79 \%$ and total lengths averaging 33 to $35 \mathrm{~mm}$. In contrast, survival and growth of male grass shrimp were conserved in the low-ration treatments. An average of $82 \%$ of male grass shrimp in all treatments survived after $12 \mathrm{wk}_{\text {; }}$ the average length increased from 23 to $27 \mathrm{~mm}$ in all treatments. It is possible that males are better intraspecific competitors for the available food. However, it is more likely that females have higher nutritional requirements because of their larger size and continuous egg production during the reproductive season. These biological characteristics may make them more susceptible to starvation than males, given the same ration. Equal division of food among the shrimp would result in males receiving a higher ration per body mass.

Despite the high rate of mortality at the lowest experimental ration, female shrimp that survived continued to produce embryos. In fact, the proportion of shrimp that were gravid at any census did not differ across food treatments (Fig. 3). It is possible that egg production in grass shrimp proceeds whether food is limited or in excess. Although the specific sources of material for vitellogenesis and oogenesis are not known for Palaemonetes pugio, it is known that nutrients, particularly lipids, involved in vitellogenesis in other crustaceans can be derived from one or both of 2 sources: (1) mobilization of stored lipids in the hepatopancreas and synthesis of lipids in ovarian tissues, and (2) direct use of dietary lipids ingested by the female (reviewed by Harrison 1990). Since production of oocytes is energetically costly (Harrison 1990), female shrimp must ingest enough material to offset what they mobilize during reproduction in order to survive and grow. If grass shrimp use both stored and ingested material for egg production, then females with severely limited food intake might not be able to replace the nutrients they mobilize. Alternatively, the quality of the eggs may be reduced due to lack of sufficient nutrients available to the female. Finally, it is possible that some shrimp in natural populations are predisposed to survive periods of food limitation. If so, then those females that survived on $1 / 4 \times$ ration may not have suffered any effects of limited food availability, and might be expected to reproduce 'normally' despite the limited food supply.

The fact that female grass shrimp maintained maximum individual reproductive effort despite lethally low levels of food does not imply that reproductive output for a field population can be sustained during periods of low food availability. Estimates of cumulative numbers of eggs produced in this study (Fig. 5) were lower at the lower food levels as a consequence of both reduced female survival and reduced body size of surviving females. The latter is an indirect effect established from the observation that smaller females bear fewer embryos. It is possible that egg number at each oviposition is predetermined, based on the size of the female and the corresponding size of the ovary. Alternatively, eggs may be produced in excess in the ovary and only a portion captured by the pleopodal setae because of the physical (size) limitations of the female abdomen. Regardless, the smaller size of females in the lower ration treatments ultimately decreased the number of larvae produced.

The proportion of gravid females across all treatments was lower after 4 and $10 \mathrm{wk}$ in the laboratory (Fig. 3). This could be a result of reproductive cycling within the population, perhaps a reflection of consecutive versus non-consecutive breeding periods (Fisher \& Clark 1983). When the presence of embryos on pleopods and oocytes in ovaries were combined into a reproductive score, a significant decline occurred at the 4 wk census, with the lowest values in the low-food treatment. By $6 \mathrm{wk}$, all other treatments had rebounded except the low-food treatment, which remained significantly low until Week 10. Such a low reproductive score $(<1)$ indicates that females did not have developing oocytes while they were gravid. Therefore, shrimp at the lowest ration may have had non-consecutive, rather than consecutive broods. This use of a combined reproductive measure provided evidence of diminished reproductive capacity at the lowest food level that was not detected by bi-weekly measurement of gravid females alone.

The hatching success of embryos was not influenced by the different food levels provided in this study. If hatching success had been high (near 100\%) in all food treatments, we might conclude that appropriate types and quantities of nutrients were available for egg production, even at the low ration treatment. However, hatching success across all treatments was extremely low relative to past studies using grass shrimp embryos (Fisher \& Foss 1993, Rayburn et al. 1996, Rayburn \& Fisher 1997), so these results must be viewed with caution. Poor hatching success may have been a consequence of handling and physical manipulation of the 
adult shrimp for measurements and examination. It is not known how a physical stress to adults could translate into poor embryo survival, yet previous work by Sandifer \& Lynn (1980) showed that handling of female Palaemonotes pugio could arrest spawning or delay oviposition. Physical handling of the shrimp may also cause loss of appendages, including chelae; such losses might restrict the ability to acquire food. The quality of the maternal diet is another possible explanation. Artemia sp. nauplii were fed at a density of 100 nauplii $1^{-1}$ water in the aquaria, a level significantly lower than the $5000 \mathrm{l}^{-1}$ typically used for rearing crustacean larvae (Welch \& Epifanio 1995). This low density was chosen to avoid artificially altering the rations while still providing essential nutrients, including cholesterol and polyunsaturated fatty acids, that most crustaceans cannot synthesize (Whitney 1969, 1970, Kanazawa \& Teshima 1971). It is possible that embryo quality suffered in all treatments due to insufficient amounts of some of these essential nutrients in the adult diet.

Finally, it is also possible that low hatching success was a consequence of factors that influenced the females before they were collected for study. In comparison with previous and subsequent years, unusually poor hatching success was observed in field collected embryos from field samples throughout the summer of 1997 (Fisher unpubl. data).

It is unknown whether the effects of nutrient limitation shown here are expressed in the field. If so, then reduction in larval recruitment would be expected during sustained periods of low food availability when female growth and survival is curtailed. Regardless of the potential importance in field situations, these findings support the need to define specific methods for feeding and handling laboratory-held grass shrimp.

Acknowledgements. The authors thank Jeanne Scott, Steve Foss and Jim Winstead, US Environmental Protection Agency, for their technical collaboration throughout the project. Jim Welch provided valuable discussion of the manuscript. This work was performed while K.A.R., P.S.G., J.R.R. and M.K.P. held National Research Council-EPA, Gulf Ecology Division Research Associateships. The work was funded in part by the Strategic Environmental Research and Development Program and in part by the Superfund Biosystems Program. This publication is Gulf Ecology Division Contribution No. 1065. Mention of commercial products herein does not constitute endorsement by the US Environmental Protection Agency.

\section{LITERATURE CITED}

Abacus Concepts (1989) SuperANOVA. Abacus Concepts, Inc, Berkeley, CA

Abacus Concepts (1992) StatView. Abacus Concepts, Inc, Berkeley, CA

Antheunisse LJ, van den Hoven NP, Jefferies DJ (1968) The breeding characters of Palaemonetes varians (Leach) (Decapoda, Palaemonidae). Crustaceana 14:259-270

Bell SS, Coull BC (1978) Field evidence that shrimp predation regulates meiofauna. Oecologia (Berl) 35:141-148

Fisher WS, Clark WH Jr. (1983) Eggs of Palaemon macrodactylus. I. Attachment to the pleopods and formation of the outer investment coat. Biol Bull (Woods Hole) 164: $189-200$

Fisher WS, Foss SS (1993) A simple test for toxicity of number 2 fuel oil and oil dispersants to embryos of the grass shrimp, Palaemonetes pugio. Mar Pollut Bull 26:385-391

Foss SS, Rayburn JR (1997) Effects of culture duration on toxicity of ethanol to developing embryos of the grass shrimp, Palaemonetes pugio. Bull Environ Contam Toxicol 59: 467-471

Glas PS, Courtney LA, Rayburn JR, Fisher WS (1997) Embryonic coat of the grass shrimp Palaemonetes pugio. Biol Bull 192:231-242

Goddard SM, Forward RB Jr (1991) The role of the underwater polarized light pattern, in sun compass navigation of the grass shrimp, Palaemonetes vulgaris. J Comp Physiol A Sens Neural Behav Physiol 169:479-491

Gunter G (1945) Studies of the marine fishes of Texas. Publ Inst Mar Sci Univ Tex 1:1-190

Harrison KE (1990) The role of nutrition in maturation, reproduction and embryonic development of decapod crustaceans: a review. J Shellfish Res 9:1-28

Hurlbert SH (1984) Pseudoreplication and the design of ecological field experiments. Ecol Monogr 54:187-211

Kanazawa A, Teshima S (1971) In vivo conversion of cholesterol to steroid hormones in the spiny lobster, Panulirus japonica. Bull Jpn Soc Sci Fish 37:211-215

Key PB, Fulton MH, Scott GI, Layman SL, Wirth EF (1998) Lethal and sublethal effects of malathion on three life stages of the grass shrimp, Palaemonetes pugio. Aquat Toxicol 40:311-322

Khan AT, Weis JS, Saharig CE, Polo AE (1993) Effect of tributyltin on mortality and telson regeneration of grass shrimp, Palaemonetes pugio. Bull Environ Contam Toxicol 50:152-157

Kneib RT (1987) Seasonal abundance, distribution and growth of postlarval and juvenile grass shrimp (Palaemonetes pugio) in a Georgia, USA, salt marsh. Mar Biol 96:215-223

Moody WD (1950) A study of the natural history of the spotted trout, Cyniscion nebulosus, in the Cedar Key, Florida, area. Q J Fla Acad Sci 12:147-171

Okazaki RK, Freeman JA (1993) Cell growth and cuticle expansion in eyestalk-ablated grass shrimp, Palaemonetes pugio Holthuis. J Crustac Biol 13:125-133

Olmi EJI, Lipcius RN (1991) Predation on postlarvae of the blue crab Callinectes sapidus Rathbun by sand shrimp Crangon septemspinosa Say and grass shrimp Palaemonetes pugio Hothuis. J Exp Mar Biol Ecol 151:169-183

Rayburn JR, Fisher WS (1997) Developmental toxicity of three carrier solvents using embryos of the grass shrimp, Palaemonetes pugio. Arch Environ Contam Toxicol 33:217-221

Rayburn JR, Fisher WS (1999) Developmental toxicity of copper chloride, methylene chloride, and 6-aminonicotinimide to embryos of the grass shrimp Palaemonetes pugio. Environ Toxicol Chem 18:950-957

Rayburn JR, Glas PS, Foss SS, Fisher WS (1996) Characterization of grass shrimp (Palaemonetes pugio) embryo toxicity tests using the water soluble fraction of number 2 fuel oil. Mar Pollut Bull 32:860-866

Riley JP, Chester R (1971) Introduction to marine chemistry. Academic Press, London

Sandifer PA, Lynn JW (1980) Artificial insemination of 
caridean shrimp. In: Clark WH Jr, Adams T (eds) Advances in invertebrate reproduction. Elsevier North Holland Inc., Amsterdam, p 271-288

Scott GI, Fulton MH, Crosby MC, Key PB, Daugomah JW (1992) Agriculture insecticide runoff effects on estuarine organisms: correlating laboratory and field toxicity tests, ecophysiology bioassays and ecotoxicological biomonitoring. US Environmental Protection Agency, Gulf Breeze Environmental Research Laboratory, Gulf Breeze, FL

Shelton ME, Chapman PJ, Foss SS, Fisher WS (1999) Degradation of weathered oil by mixed marine bacteria and the toxicity of accumulated water-soluble material to two marine Crustacea. Arch Environ Contam Toxicol 36:13-20

Sokal RR, Rohlf FJ (1981) Biometry. The principles and practice of statistics in biological research, 2nd edn. WH Freeman \& Co, New York

Sverdrup HU, Johnson MW, Fleming RH (1942) The oceans. Prentice-Hall, Inc, Englewood Cliffs, NJ

Tatem HE, Anderson JW, Neff JM (1976) Seasonal and laboratory variations in the health of grass shrimp Palaemonetes pugio; dodecyl sodium sulfate bioassay. Bull Environ Contam Toxicol 16:368-375

Vernberg FJ, Piyatiratitivorakul S (1998) Effects of salinity and temperature on the bioenergetics of adult stages of the grass shrimp (Palaemonetes pugio Holthuis) from the North Inlet Estuary, South Carolina. Estuaries 21:176-193

Weis JS, Cristini A, Rao KR (1992) Effects of pollutants on molting and regeneration in crustacea. Am Zool 32:495-500

Welch JM, Epifanio CE (1995) Effect of variations in prey abundance on growth and development of crab larvae reared in the laboratory and in large field-deployed enclosures. Mar Ecol Prog Ser 116:55-64

Welsh BL (1975) The role of grass shrimp, Palaemonetes pugio, in a tidal marsh ecosystem. Ecology 56:513-530

Editorial responsibility: Kenneth Heck (Contributing Editor), Dauphin Island, Alabama, USA
Wenner C (1995) Red drum: natural history and fishing techniques in South Carolina. South Carolina Department of Natural Resources, Charleston

Wenner C, Archambault J (1996) Spotted seatrout: natural history and fishing techniques in South Carolina. South Carolina Department of Natural Resources, Charleston

White (1949) Preliminary notes on the breeding season of Palaemonetes kadiakensis Rathbun in the Baton Rouge area. Proc La Acad Sci 12:71-74

Whitney JO (1969) Absence of sterol synthesis in larvae of the mud crab Rhithropanopeus harrisii and of the spider crab Libinia emarginata. Mar Biol 3:134-145

Whitney JO (1970) Absence of sterol biosynthesis in the blue crab Callinectes sapidus Rathbun and in the barnacle Balanus nubilus Darwin. J Exp Mar Biol Ecol 4:229-237

Williams AB (1984) Shrimps, lobsters, and crabs of the Atlantic coast of the eastern United States, Maine to Florida. Smithsonian Press, Washington, DC

Wilson JE (1985) Sublethal effects of diflubenzuron (Dimlin) on the reproduction and photobehavior of the grass shrimp Palaemonetes pugio Holthuis. PhD thesis, Duke University, Durham, NC

Wilson JE, Forward RB Jr, Costlow JD (1985) Effects of embryonic exposure to sublethal concentrations of Dimlin on the photobehavior of grass shrimp larvae. In: Vernberg FJ et al. (eds) Marine pollution and physiology: recent advances. University of South Carolina Press, Belle W Baruch Library in Marine Science, Columbia, SC, p 377-396

Wood CE (1967) Physioecology of the grass shrimp, Palaemonetes pugio, in the Galveston Bay estuarine system. Contrib Mar Sci 12:54-79

Zar JH (1996) Biostatistical analysis, 3rd edn. Prentice-Hall, Upper Saddle River, NJ

Submitted: March 18, 1999; Accepted: February 2, 2001

Proofs received from author(s): September 11, 2001 